ISSN 0974-3618 (Print) 0974-360X (Online) www.rjptonline.org
ARJPT

$\underline{\text { RESEARCH ARTICLE }}$

\title{
Essential and Toxic Microelements in the Medicinal Remedy Hyperichi herba by Different Producers
}

\author{
Tetiana M. Derkach ${ }^{1 *}$, Volodymyr G. Khomenko ${ }^{2}$ \\ ${ }^{1}$ Department of Industrial Pharmacy, Kyiv National University of Technologies and Design, Nemirovicha- \\ Danchenko Str, 2, Kyiv, 01011, Ukraine \\ ${ }^{2}$ Department of Electrochemical Energetics and Chemistry, Kyiv National University of Technologies and \\ Design, Nemirovicha-Danchenko Str, 2, Kyiv, 01011, Ukraine \\ *Corresponding Author E-mail: derkach.tm@knutd.edu.ua
}

\begin{abstract}
:
The elemental composition of herbal remedy, Hyperichi herba, grown in different regions of Ukraine and supplied by three different producers, was studied by flame atomic absorption spectroscopy. The concentrations of essential microelements $\mathrm{Fe}, \mathrm{Cu}, \mathrm{Mn}$ and $\mathrm{Zn}$, as well as toxic metals $\mathrm{Pb}, \mathrm{Cd}, \mathrm{Cr}$ and $\mathrm{Co}$ were determined and compared with the available literature data. The significant difference between samples from different producers is observed for $\mathrm{Mn}, \mathrm{Co}$, and $\mathrm{Cd}$. The higher the Fe content, the lower $\mathrm{Mn}$ and $\mathrm{Zn}$ concentrations are detected in individual samples. The concentration of $\mathrm{Cu}$ is rather stable. Cadmium is detected in samples of one producer only while in others it is below the detection limit. Relatively small concentrations of $\mathrm{Pb}$ are detected in all samples. Chromium is below the detection limit in all studied plants. The elemental composition of plants collected by one producer is characterised by higher $\mathrm{Mn}$ and $\mathrm{Cd}$ concentrations compared to other samples. The observed Mn enrichment correlates well with an increased content of this element in regional rivers which is virtually independent of an anthropogenic impact on the environment. The principal component analysis was used to minimise the number of variables. Three principal components composed of the concentrations of all essential and some non-essential microelements are sufficient to explain $91 \%$ of the total variance.
\end{abstract}

KEYWORDS: Medicinal plants, atomic absorption spectroscopy, Elemental composition, toxic metal contamination, Principal component analysis.

\section{INTRODUCTION:}

Last decades, the use of medicinal plants has been remarkably increasing that is in line with the global trend of people returning to nature-cure ${ }^{1,2}$. It is often taken as an axiom that herbal medicines are less toxic for the human organism compared to synthetic substances $^{3,4}$. However, such an opinion oversimplifies the real situation ${ }^{5-7}$. Conventional medicines are purified compounds, and clinical trials establish their safe doses.

Received on 20.09.2017 Accepted on 04.01.2018

Modified on 08.11.2017

Research J. Pharm. and Tech 2018; 11(2):466-474.

DOI: 10.5958/0974-360X.2018.00086.0
Ingress of any extraneous substances is controlled in all manufacturing stages. On the contrary, medicinal plants may contain a large variable number of chemical compounds and elements. The quality assessment of medicinal plants mainly focuses on the availability of active pharmaceutical ingredients (APIs) while the content of various metals and metalloids may vary in a wide range. There has been an increasing number of research focusing on the elemental compositions of medicinal plants to assess their safety for public consumption $^{8-10}$. Medicinal plants are cultivated with a range of agricultural practices under different ecological conditions. Since the high number of species and different plant organs are used, a high botanical variability in plant compounds is also observed ${ }^{11-13}$. All these factors determine diversity in the chemical composition of medicinal plants. 
For example, medicinal plants can accumulate toxic metals. The accumulation degree depends on their individual properties and the concentration of heavy metals in soil, air and water ${ }^{14-16}$. As heavy metals threaten human and animal health, their content in plants used for consumption or medicinal purposes must be limited. The international organisations recommend checking medicinal plants for the concentrations of heavy toxic metals, and maximum allowed limits are set for $\mathrm{Hg}, \mathrm{Pb}, \mathrm{Cd}$ and As. Nevertheless, there are known many studies documenting high concentrations of certain toxic elements compared to their safe/tolerable exposures $^{17-19}$.

Some other microelements have a direct influence on the development of plant organisms. They participate in biochemical processes and are known as essential elements for plants ${ }^{15}$. Many elements being essential for the plant development may be simultaneously toxic to human health depending on $\operatorname{dos}^{20}$. In contrast to toxic heavy metals, the content of essential elements is not controlled and restricted in herbal medicines.

In spite of a great variety of the chemical composition, the availability of medicinal plants is almost entirely unrestricted, as no prescription from doctors is required to purchase. Producers of herbal medicines readily describe plants and their parts used for remedy manufacturing, specify moisture and storage conditions. Sometimes they specify a region of herb gathering or assert that plants were grown and collected under ecological conditions. They often declare that a remedy was produced by good agricultural and collection practice (GACP). According to the GACP, seeds or planting stock and cultivating conditions are standardised with compulsory documenting ${ }^{21-23}$. The influence of impurities on the finished medicinal product is believed to be ruled out by controlling the cultivation of plants from the time of seed.

In Ukraine, the GACP rules are not compulsory conditions for herbal medicines. By this reason, perhaps, no information on the elemental composition is shown on the boxes with medicinal herbs. Nevertheless, many plants can accumulate a considerable amount of microelements. One can suppose that the lack of regulation on the manufacturing of herbal medicines allows potentially harmful quantities of both toxic and essential trace elements to be in the products under certain conditions. Therefore, the stability of high quality of herbal raw materials is still questionable. Therefore, determining elemental compositions of medicinal plants should be of particular concern. The paper goal is to study elemental composition of samples of the herbal remedy, Hyperici Herba, grown and collected in different regions of Ukraine to estimate possible effect of a location of the herbs picking.

\section{MATERIALS AND METHODS: Sample Preparation:}

The specimens of herbal remedy, Hyperici Herba, commonly known as St John's wort (SJW) and supplied by three different producers, were bought at local pharmacies in Kiev, Ukraine. Producers 1, 2 and 3 supply medicinal plants collected in the central (Zhytomyr Region), eastern (Zaporizhzhya Region) and western (Ternopil Region) parts of the country respectively which are separated by a distance of 400$500 \mathrm{~km}$ from each other. Before analysis, the samples were ground in a high-speed rotor mill to obtain a homogeneous sample with grain diameters of $\leq 1 \mathrm{~mm}$ and stored in polyethylene containers.

All chemicals purchased from commercial sources were of analytical grade. Accurately weighed plant samples (approx. $2 \mathrm{~g}$ ) were placed into a Teflon reaction crucible and treated with $10 \mathrm{ml}$ of $30 \%$ hydrogen peroxide $\left(\mathrm{H}_{2} \mathrm{O}_{2}\right)$ / concentrated $65 \% \quad \mathrm{HNO}_{3} \quad(1: 4, \mathrm{v} / \mathrm{v})$. Decomposition of the samples was carried out in a closed-vessel microwave digestion system. The digestion program consisted of three stages and was as follows: $80 \%$ power for $15 \mathrm{~min}, 100 \%$ for $5 \mathrm{~min}$ and $80 \%$ power for $20 \mathrm{~min}$. After cooling, the clear digested solutions were transferred quantitatively into clean volumetric flasks and made up to $50 \mathrm{ml}$ with twice distilled water. Blank experiments were carried out in the same way. Three independent digestions were performed for each plant specimen. The digests were used to determine concentrations of trace elements by flame atomic absorption spectroscopy (FAAS).

\section{Instrumentation:}

The concentrations of $\mathrm{Cu}, \mathrm{Zn}, \mathrm{Fe}, \mathrm{Mn}, \mathrm{Pb}, \mathrm{Cd}$, Co and $\mathrm{Cr}$ were determined using a double-beam Solaar S4 AA Spectrometer (Thermo Electron Co., USA), applying standard conditions in air/acetylene flame and using $\mathrm{D}_{2}$ correction. The quantitative determinations were carried out by external calibration with the use of certified reference materials for metallic ions produced by Bogatsky Physics and Chemistry Institute (Odessa, Ukraine).

The working range for each element was within a linear range of the method. Calibration intervals were adjusted according to the expected concentrations of elements. The sensitivity of the method with respect to each metal was evaluated using the resulted slope of the calibration curves. Measurement of each sample was repeated three times, and the mean value was calculated. Table 1 illustrates the instrument operating conditions. 
Table 1: Operating conditions for the flame AAS method

\begin{tabular}{|l|l|l|l|l|}
\hline Element & Analyte wavelength, $\mathbf{n m}$ & Working range, $\boldsymbol{\mu g} / \mathbf{l}$ & Slit width, $\mathbf{n m}$ & Characteristic concentration, $\boldsymbol{\mu g} / \mathbf{l}$ \\
\hline $\mathbf{F e}$ & 248.3 & $0.5 \div 5.0$ & 0.2 & 0.061 \\
\hline $\mathbf{M n}$ & 279.5 & $0.5 \div 3.0$ & 0.2 & 0.035 \\
\hline $\mathbf{C u}$ & 324.7 & $0.5 \div 4.0$ & 0.5 & 0.033 \\
\hline $\mathbf{Z n}$ & 213.9 & $0.5 \div 2.0$ & 0.2 & 0.030 \\
\hline $\mathbf{P b}$ & 283.3 & $0.5 \div 10.0$ & 0.2 & 0.320 \\
\hline $\mathbf{C d}$ & 228.8 & $0.5 \div 2.0$ & 0.5 & 0.023 \\
\hline $\mathbf{C r}$ & 357.9 & $0.5 \div 5.0$ & 0.5 & 0.100 \\
\hline $\mathbf{C o}$ & 240.8 & $0.5 \div 4.0$ & 0.2 & 0.077 \\
\hline
\end{tabular}

\section{Statistical Analysis:}

Both own experimental results and available literature data were analysed by statistical methods using IBM SPSS Statistics 20 software. All data were tested for normal distribution with the Shapiro-Wilks model and variance homogeneity with the Levene's test. The results were expressed either as the means $\left(\mathrm{C}_{\mathrm{m}}\right)$ with standard errors of the mean (SEM) for data with a normal distribution or medians $\left(\mathrm{C}_{\mathrm{med}}\right)$ and quartiles $\left(\mathrm{Q}_{25}\right.$, $\mathrm{Q}_{50}$ and $\mathrm{Q}_{75}$ ) for asymmetric distributions.

One-way analysis of variance (ANOVA) was used to analyse possible differences among the mean concentrations. The significance level $\alpha$ was set at or below $5 \%(\alpha \leq 0.05)$. If the significant differences were found to exist among the means, then post hoc pairwise multiple comparisons were applied to make direct comparisons between two means from two individual groups and determine which means differ. Depending on the results of Levene's tests, either the least significant difference or Tamhane's T2 methods were used in post hoc comparisons for equal or unequal variances respectively.

We used the method of principal component analysis (PCA), the simplest type of factor analysis, with an orthogonal Varimax rotation and Kaiser normalisation. It allows one to simplify structures and illustrate large data sets, by calculating a smaller number of meaningful linear combinations (principal components) from a large number of variables (element concentrations). In essence, this method consists in the selection of a new orthogonal coordinate system in observation space. As the first principal component (PC), a direction, along which an array of observations has the largest variance, is selected. In other words, the first task of PCA is to select interacting variables, whose cross-correlation determines the largest share of the total variance. These variables constitute the first PC. Then the first PC is excluded from further consideration. Next PCs are also selected to maximise a remaining part of the total variant. Orthogonality between all PCs is an additional condition for PC mapping. Evidently, a part of the total variance linked to a given PC decreases with its number.

\section{RESULTS:}

The measured concentrations of microelements in individual samples are shown in Table 2. The data obtained allow one to estimate a general level of concentrations and elemental variability in going from one producer to another. The concentrations of $\mathrm{Fe}$ and Mn range roughly from 26 to $55 \mu \mathrm{g} / \mathrm{g}$ and from 55 to $138 \mu \mathrm{g} / \mathrm{g}$ respectively. The $\mathrm{Zn}$ and $\mathrm{Cu}$ concentrations are typically much lower. They change from 17 to $31 \mu \mathrm{g} / \mathrm{g}$ and from 5 to $12 \mu \mathrm{g} / \mathrm{g}$ respectively. $\mathrm{Pb}$ is detected in all studied samples. Cadmium is detected in samples of producer 3 only. Cobalt is observed in samples of producers 1 and 3 . The $\mathrm{Cr}$ concentrations are below the detection limits in all studied samples. Some of the studied elements, such as $\mathrm{Fe}, \mathrm{Mn}, \mathrm{Cu}$ and $\mathrm{Zn}$, have significant metabolic functions in the human body and plants, thus being essential elements. Chromium has stimulating effects on plant growth. However, it is not considered as an essential microelement for plants ${ }^{15}$ because its functions are not completely recognised yet. Cobalt is known to be an essential microelement in plants because it is involved in symbiotic $\mathrm{N}_{2}$ fixation and valence changes stimulation synthesis of chlorophyll and proteins ${ }^{15}$.

Table 2: Element concentrations $(\mu \mathrm{g} / \mathrm{g})$ in individual samples supplied by different producers

\begin{tabular}{|l|l|l|l|l|l|l|l|l|}
\hline Producer & Fe & $\mathbf{C u}$ & $\mathbf{M n}$ & $\mathbf{Z n}$ & $\mathbf{C d}$ & $\mathbf{P b}$ & $\mathbf{C o}$ & $\mathbf{C r}$ \\
\hline $\mathbf{1}$ & 42.53 & 9.45 & 105.77 & 26.39 & $<0.023$ & 0.413 & 0.185 & $<0.376$ \\
\hline $\mathbf{1}$ & 26.74 & 11.85 & 103.99 & 20.89 & $<0.023$ & 0.328 & 0.190 & $<0.376$ \\
\hline $\mathbf{1}$ & 46.17 & 7.63 & 97.39 & 31.42 & $<0.023$ & 0.325 & 0.263 & $<0.376$ \\
\hline $\mathbf{2}$ & 46.06 & 5.02 & 64.08 & 22.41 & $<0.023$ & 0.385 & $<0.077$ & $<0.376$ \\
\hline $\mathbf{2}$ & 55.52 & 6.50 & 77.01 & 16.55 & $<0.023$ & 0.320 & $<0.077$ & $<0.376$ \\
\hline $\mathbf{2}$ & 49.50 & 5.52 & 55.96 & 19.88 & $<0.023$ & 0.345 & $<0.077$ & $<0.376$ \\
\hline $\mathbf{3}$ & 26.11 & 7.77 & 137.72 & 28.80 & 0.891 & 0.335 & 0.085 & $<0.376$ \\
\hline $\mathbf{3}$ & 35.67 & 8.04 & 132.29 & 28.20 & 0.834 & 0.612 & 0.318 & $<0.376$ \\
\hline $\mathbf{3}$ & 29.73 & 7.00 & 135.00 & 30.05 & 0.851 & 0.539 & 0.210 & $<0.376$ \\
\hline Average 1-3 & $39.78 \pm 3.55$ & $7.64 \pm 0.69$ & $101.02 \pm 10.2$ & $24.96 \pm 1.73$ & $0.859 \pm 0.02$ & $0.400 \pm 0.04$ & $0.205 \pm 0.03$ & $<0.376$ \\
\hline
\end{tabular}


Cadmium and lead are among the most toxic elements for both human body and plants. Both Co and Cr, being essential elements for the human body, nevertheless, are rather toxic. Modern pharmacopoeias attribute $\mathrm{Cd}$ and $\mathrm{Pb}$ to Class 1 , Co to Class $2 \mathrm{~A}$ and $\mathrm{Cr}$ to Class 3 and establish permitted daily exposures (PDE) based on their toxicity ${ }^{24}$. Due to their pronounced toxicity, we combine

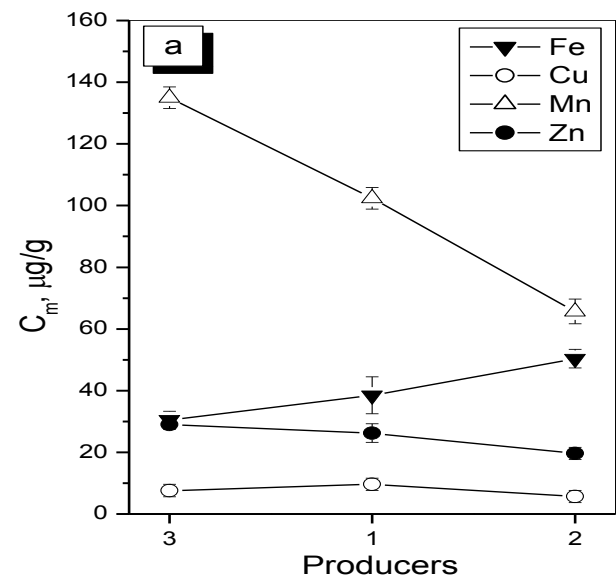

Fig. 1: Mean concentrations $C_{m}$, with SEM $\left({ }^{\square} \mathrm{g} / \mathrm{g}\right)$ of essential (a) and toxic (b) microelements in samples of SJW supplied by three different producers (1-3)

The significant differences between samples of the various suppliers for $\mathrm{Mn}, \mathrm{Co}$ and $\mathrm{Cd}$ and no differences for $\mathrm{Zn}, \mathrm{Cu}, \mathrm{Fe}$ and $\mathrm{Pb}$ were found by ANOVA tests (Table 3). Samples of producer 1 contain more $\mathrm{Mn}$ compared to samples of producer 2, but the highest
$\mathrm{Cd}, \mathrm{Pb}, \mathrm{Cr}$ and $\mathrm{Co}$ into a group of toxic metals for convenience. More conclusions can be formulated, if the plants under study are arranged in order of increasing or falling concentration of a particular element. The mean concentrations of essential and toxic microelements in samples of SJW supplied by producers from different regions are shown in Fig. 1.

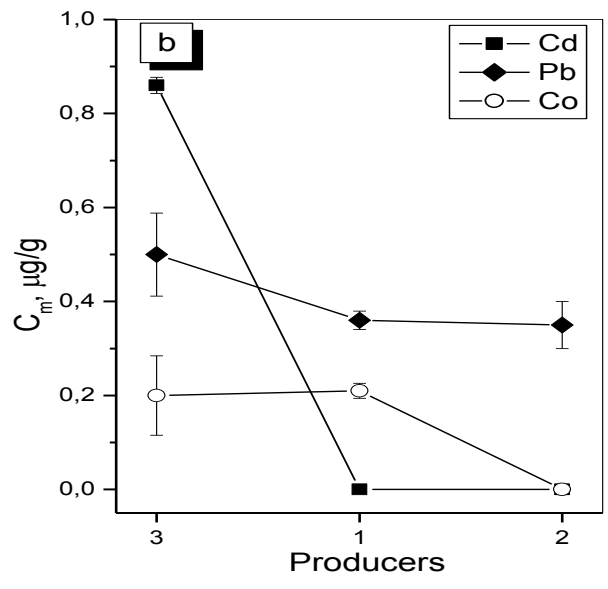

concentration of $\mathrm{Mn}$ is in samples of producer 3. The significant difference in Mn content can be considered as an evidence of substantial contamination of some samples by $\mathrm{Mn}$. The higher the Mn concentration, the lower the Fe concentration is detected.

Table 3: ANOVA tests for comparison of $\mathrm{C}_{\mathrm{m}}$ in samples of different producers

\begin{tabular}{|c|c|c|c|c|c|c|}
\hline & & Sum of squares & df & Mean square & $\mathbf{F}$ & $\alpha$ \\
\hline \multirow[t]{3}{*}{$\mathbf{F e}$} & Between groups & 2781.003 & 2 & 1390.502 & 3.227 & 0.076 \\
\hline & Within groups & 5171.230 & 12 & 430.936 & & \\
\hline & Total & 7952.233 & 14 & & & \\
\hline \multirow[t]{3}{*}{$\mathrm{Cu}$} & Between groups & 12.708 & 2 & 6.354 & 1.556 & 0.251 \\
\hline & Within groups & 49.009 & 12 & 4.084 & & \\
\hline & Total & 61.717 & 14 & & & \\
\hline \multirow[t]{3}{*}{ Mn } & Between groups & 9241.624 & 2 & 4620.812 & 8.468 & $0.003(*)$ \\
\hline & Within groups & 8184.982 & 15 & 545.665 & & \\
\hline & Total & 17426.606 & 17 & & & \\
\hline \multirow[t]{3}{*}{$\mathbf{Z n}$} & Between groups & 221.745 & 2 & 110.873 & 1.141 & 0.352 \\
\hline & Within groups & 1165.656 & 12 & 97.138 & & \\
\hline & Total & 1387.401 & 14 & & & \\
\hline \multirow[t]{3}{*}{ Cd } & Between groups & 1.475 & 2 & 0.738 & 2545.080 & $0.000(*)$ \\
\hline & Within groups & 0.002 & 6 & 0.000 & & \\
\hline & Total & 1.477 & 8 & & & \\
\hline \multirow[t]{3}{*}{$\mathbf{P b}$} & Between groups & 173.500 & 2 & 86.750 & 0.942 & 0.441 \\
\hline & Within groups & 552.648 & 6 & 92.108 & & \\
\hline & Total & 726.148 & 8 & & & \\
\hline \multirow[t]{3}{*}{ Co } & Between groups & 0.091 & 2 & 0.045 & 6.260 & $0.034(*)$ \\
\hline & Within groups & 0.044 & 6 & 0.007 & & \\
\hline & Total & 0.134 & 8 & & & \\
\hline
\end{tabular}

(*) Differences are significant at the 0.05 level (2-tailed)

\section{DISCUSSION:}

Volatility of chemical composition of plants:

Figure 1 illustrates the observed differences between samples in the mean concentrations which are 
below the detection limit in the samples of producer 2 that differences them from other plants. The concentration differences between samples for all other elements are within experimental errors. There are known many published works which are devoted to the study of the elemental composition of St John's wort. We analysed the results of 12 publications ${ }^{16,25-35}$. All these results from now on referred to as the literature data and marked with index lit are compared with some experimental data (index exp) obtained in the given research. A large spread in the measured elemental concentrations is typical for the literature data. As follows from the Shapiro-Wilks test, only $\mathrm{Co}, \mathrm{Cd}$ and Mn distributions obey the normal law while all other elements show asymmetrical distributions with pronounced skewness and kurtosis. Both mean values with SEM and medians with other characteristics of asymmetrical curves were calculated and shown in Table 4 to characterise the literature data.

Table 4: Statistics for the literature data ${ }^{16,25-35}$

\begin{tabular}{|c|c|c|c|c|c|c|c|c|}
\hline & $\mathbf{Z n}$ & Cd & Co & $\mathbf{P b}$ & $\mathrm{Cr}$ & $\mathrm{Cu}$ & $\mathrm{Fe}$ & Mn \\
\hline Distribution & Skew & Normal & Normal & Skew & Skew & Skew & Skew & Normal \\
\hline$C_{m}($ lit $)$ of peak 1 & 39.92 & 0.06 & 0.45 & 2.00 & 0.98 & 12.04 & 148.63 & 15.5 \\
\hline SEM of peak 1 & 5.79 & 0.03 & 0.03 & 0.20 & 0.14 & 2.05 & 21.92 & 2.4 \\
\hline$C_{m}($ lit $)$ of peak 2 & & 0.8 & & & & & & 124.5 \\
\hline SEM of peak 2 & & 0.3 & & & & & & 30 \\
\hline $\mathrm{C}_{\text {med }}($ lit $)$ & 33.70 & 0.49 & 0.44 & 1.80 & 0.49 & 9.50 & 74.00 & 21.90 \\
\hline $\mathrm{C}_{\min }$ (lit) & 7.00 & 0.05 & 0.10 & 1.60 & 0.12 & 1.60 & 1.20 & 2.40 \\
\hline $\mathrm{C}_{\max }$ (lit) & 400.00 & 1.78 & 0.85 & 2.70 & 5.00 & 120.00 & 760.00 & 261.00 \\
\hline Skewness & 7.10 & 0.89 & 0.23 & 1.13 & 1.79 & 5.50 & 2.19 & 1.26 \\
\hline Kurtosis & 54.75 & 0.44 & 0.70 & 0.24 & 3.99 & 32.02 & 4.27 & 1.01 \\
\hline $\mathbf{Q}_{25}$ & 24.50 & 0.07 & 0.34 & 1.65 & 0.27 & 7.53 & 49.50 & 11.36 \\
\hline$Q_{50}$ & 33.70 & 0.49 & 0.44 & 1.80 & 0.49 & 9.50 & 74.00 & 21.90 \\
\hline $\mathbf{Q}_{75}$ & 42.01 & 0.80 & 0.51 & 2.45 & 1.60 & 11.29 & 171.50 & 89.00 \\
\hline
\end{tabular}

As seen from Table 4 and Fig. 1, the measured mean concentrations of $\mathrm{Zn}$ and $\mathrm{Cu}$ are rather close in magnitude to the median values derived from the literature. On the contrary, the $\mathrm{C}_{\mathrm{m}}(\exp )$ values for $\mathrm{Pb}$, $\mathrm{Fe}, \mathrm{Co}$ and $\mathrm{Cr}$ are much lower than the $\mathrm{C}_{\text {med }}$ (lit) or $\mathrm{C}_{\mathrm{m}}$ (lit), being located within the quartile $\mathrm{Q}_{25}$ in the published datasets. The concentration distributions of the literature data for these elements have positive skews and are characterised by longer right tails. In other words, very high concentrations of $\mathrm{Fe}, \mathrm{Pb}, \mathrm{Cr}$ or $\mathrm{Co}$ were observed by some authors, such as e.g. $1200 \mu \mathrm{g} / \mathrm{g}$ Fe (16 times as many as $\left.\mathrm{C}_{\text {med }}(\text { lit })^{26}\right), 8 \mu \mathrm{g} / \mathrm{g} \mathrm{Pb}^{36}, 2.6$ $\mu \mathrm{g} / \mathrm{g} \mathrm{Co}^{37}, 3.7 \mu \mathrm{g} / \mathrm{g} \mathrm{Cr}^{26}$, etc. Such abnormally high data shift both the mean and median concentrations to a higher concentration range compared to the mean values measured in our experiments.

In turn, both $\mathrm{Mn}$ and $\mathrm{Cd}$ by the literature data demonstrate two Gaussian peaks. For example, the $\mathrm{Cd}$ concentration is less than $0.5 \mu \mathrm{g} / \mathrm{g}$ with an average $\mathrm{C}_{\mathrm{m}}$ (lit) $0.06 \mu \mathrm{g} / \mathrm{g}$ in 29 of 64 published results (Fig. 2). In turn, the mean $\mathrm{Cd}$ concentration approximates to 0.8 $\mu \mathrm{g} / \mathrm{g}$ in the rest 35 samples which are more contaminated and form the second Gaussian peak. By analogy with $\mathrm{Cd}$, two peaks close to 65 and $135 \mu \mathrm{g} / \mathrm{g}$ are observed for Mn (Fig. 2). Therefore, two modes of SJW plants with lower and higher concentrations of $\mathrm{Mn}$ and $\mathrm{Cd}$ are observed in the literature.
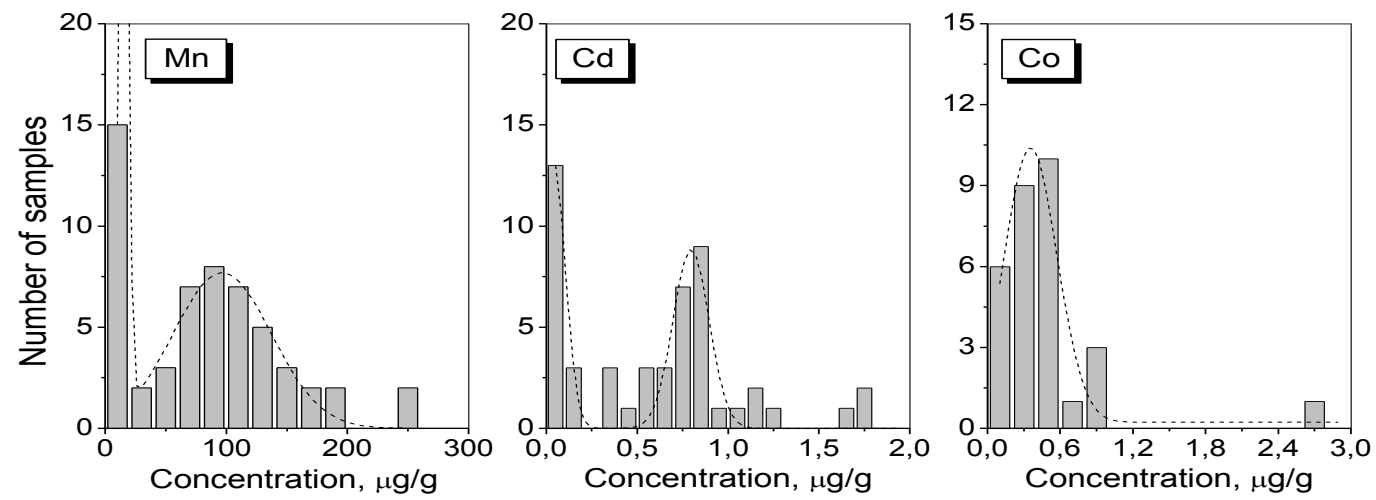

Fig. 2: Histograms illustrate $\mathrm{Mn}, \mathrm{Cd}$ and $\mathrm{Co}$ concentration distributions by the literature data

The compositions of the studied samples qualitatively agree with the literature data. In particular, the samples of producer 3 show the highest concentrations of $\mathrm{Mn}$ $\left(\mathrm{C}_{\mathrm{m}}(\exp )=135 \mu \mathrm{g} / \mathrm{g}\right)$ and $\mathrm{Cd}\left(\mathrm{C}_{\mathrm{m}}(\exp )=0.86 \mu \mathrm{g} / \mathrm{g}\right)$ 
among all samples. On the contrary, the samples of producer 2 are characterised by the lowest $\mathrm{Mn}$ concentration $\left(\mathrm{C}_{\mathrm{m}}(\exp )=65 \mu \mathrm{g} / \mathrm{g}\right)$ and together with samples of producer 1 they have the lowest $\mathrm{Cd}$ content (below the detection limit). Therefore, the samples of producers 2 and 3 can be considered as weakly and strongly contaminated plants respectively. The mean experimental concentrations of $\mathrm{Mn}$ and $\mathrm{Cd}$ of producer 3 samples are very close to the mean values of peaks 2 calculated from the literature data (Fig. 2) while these concentrations are somewhat higher than the $\mathrm{C}_{\mathrm{m}}$ (lit) values of peak 1 in samples of producer 2 .

Evidently, the volatility of the chemical composition of same plants depends on cultivation conditions, further processing and storage. The primary sources of trace elements are plants' growth surroundings, including soil, water, atmospheric depositions, and nutrient solutions. The uptake of trace elements by plants is affected, in addition to plant-specific ability, by soils factors, of which the most significant are $\mathrm{pH}$, water regime, clay content, nutrient balance, concentrations of other elements, climatic conditions, etc. ${ }^{15}$. Plants readily absorb the species of elements that are dissolved in the ground solutions in either ionic or chelated and complexed form. On the contrary, low solubility typically reduces the availability of elements in plants.

As a result, some elements are more susceptible to phytoavailability than others. For example, Ag, Cr, Sn, $\mathrm{Ti}$, and Y are very slightly soluble in soil solution ${ }^{15}$. The low solubility complicates their penetration through soil layers into plant tissues, and they are not easily taken up by plants. Other elements, such as $\mathrm{As}, \mathrm{Hg}, \mathrm{Pb}$ and $\mathrm{F}$, are not readily transported to above-ground parts of plants because they are relatively strongly bound with soil components. Many other elements, including $\mathrm{Mn}, \mathrm{Cd}$, $\mathrm{Zn}, \mathrm{B}, \mathrm{Co}, \mathrm{Cu}, \mathrm{Mo}$, and $\mathrm{Ni}$, are mobile in soil and readily taken up by plants. In SJW, such soluble elements are detected in a majority of research ${ }^{16,25-35}$ in contrast to insolubles.

As follows from Table 2, the medicinal plants of producer 3 collected in Ternopil region are characterised by significantly higher $\mathrm{Mn}$ and $\mathrm{Cd}$ contents compared to plants collected in other areas. The content and dynamics of seasonal migration of heavy metals, including $\mathrm{Mn}, \mathrm{Fe}, \mathrm{Co}, \mathrm{Pb}$, and $\mathrm{Zn}$, have been recently analysed in small rivers of Ternopil region ${ }^{38}$. The territory of Ternopil region was divided into 4 parts, namely agricultural (AL), urbanised (UL), recreation lands (RL), and lands transformed by a high anthropogenic impact (TL). All measured concentrations were determined relative to maximum permissible concentrations (MPCs) in the form of pollution coefficients. The MPCs for river water are set down by government authorities of Ukraine. Only Co concentrations among chemical elements under discussion were below the MPC in all studied lands and seasons. In most cases, the $\mathrm{Pb}$ concentrations were below the MPC except for some samples from TL where the $\mathrm{Pb}$ pollution coefficient increased to 1.2. A moderate $\mathrm{Zn}$ pollution is observed in all lands, and its level varies between 1.3 and 2.7 depending on land types and seasons. In contrast to the elements mentioned above, the river water is heavily polluted with $\mathrm{Mn}$ and $\mathrm{Fe}$ in all lands. The Mn pollution coefficients are strong functions of seasons and vary between 3.3 and 14 for RL, $<1$ and 6.1 for UL, 2.5 and 4.2 for AL, and 4.3 and 7.5 for TL. For $\mathrm{Fe}$, the maximal seasonal values the pollution coefficients are 8.8, 3.7, 5.6 and 9.2 for RL, UL, AL and TL respectively.

In fact, no correlation between the detected $\mathrm{Mn}$ and $\mathrm{Fe}$ contamination of water bodies and the environmental load was observed in $^{38}$ because both recreation lands and lands transformed by a high anthropogenic impact demonstrate similar levels of the pollution coefficients. In addition to anthropogenic factors, the excess in $\mathrm{Mn}$ and $\mathrm{Fe}$ concentration in river water is caused by the occurrence of these elements in abiotic components of river valleys, particularly in areas with iron and manganese, alluvial deposits, clay soils with ferrous metal compounds and leaching of elements from rock, soil and forest litter ${ }^{38}$.

The results obtained attract attention to the problem of variability of the elemental composition of medicinal plants. On the one hand, such volatility enhances risks of bioaccumulation of toxic elements in plants grown even under conditions of recreation lands. On the other hand, it opens new aspects of nutrition of plants by necessary elements to adjust their intake to the food chain.

\section{Safe daily intakes:}

In addition to essential elements, plants reveal various tendencies in the uptake of other trace elements. There are known many research works in the literature, reporting heavy contamination of plants by many toxic elements ( $\mathrm{Hg}, \mathrm{Pb}$, As, etc.). For example, St John's wort was observed to accumulate $\mathrm{Cd}^{34,35}$. Cadmium is detected at a level of $0.8 \mu \mathrm{g} / \mathrm{g}$ in plants of producer 3 but is absent in other studied samples. As seen from Fig. 2, the $\mathrm{Cd}$ histogram can be approximated by a two-peak Gaussian. One of these peaks describes Cd-free samples while the mean concentration $\mathrm{C}_{\mathrm{m}}$ (lit) of another peak is similar to $\mathrm{C}_{\mathrm{m}}(\exp )$. Lead is observed in samples of all producers with no significant difference between them. The measured $\mathrm{C}_{\mathrm{m}}(\mathrm{exp})$ concentrations of $\mathrm{Pb}$ are on average lower than the $\mathrm{C}_{\text {med }}$ (lit) value derived from the literature. Many elements, being essential for plant growth, can, however, have toxic effects on cells at 
higher concentrations. Hypothetical reactions of plants to increasing concentrations of the essential and nonessential elements are schematically shown in Fig. 3. Essential elements are characterised by an optimal concentration range which provides the best conditions for organism growth while non-essential or toxic elements can impede plant growth from deficient concentrations. Both deficit and excess of essential elements can disorder metabolic cycles and provoke abnormal or stunted growth of the plant.

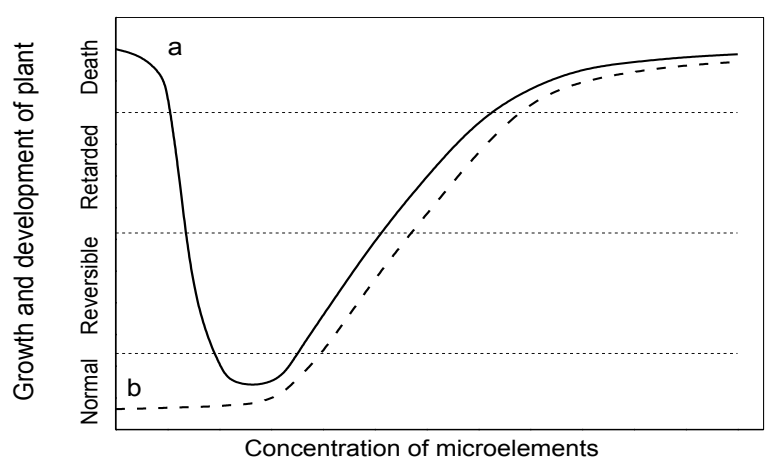

Fig. 3 Schematic diagram ${ }^{27}$ of plant response to stress from deficiency and toxicity of microelements: a - essential microelements; b - non-essential (toxic) microelements
Many organisations in the world study the influence of chemical elements on human health and develop recommendations and restrictions on their daily consumption. Some recommendations determine optimal daily intakes of elements essential for the human organism and they are referred to as Levels of Optimal Consumption (LOC). Other recommendations focus on the restriction of daily consumption of both essential and non-essential toxic elements. Such recommendations represent Upper Limits of Safe Consumption (ULSC).

The LOC and ULSC ranges by the different authorities ${ }^{24,39-44}$ together with concentration ranges detected in our experiments are shown for in Table 5. The ratios of ULSC to the maximal concentrations observed in the experiment estimate safe limits of daily intakes of the most contaminated herbs from the viewpoint of possible side effect of the microelements, as is illustrated in Table 5. Though all studied samples show microelement contents within the acceptable limits, one-time ingestion of more than 22-80 $\mathrm{g}$ of the most contaminated herbs may result to overriding of the ULSC parameter in $\mathrm{Cd}$ and $\mathrm{Mn}$ respectively.

Table 5: LOC and ULSC ${ }^{24,39-44}$ and experimental concentration ranges

\begin{tabular}{|l|l|l|l|l|l|}
\hline & LOC $(\mathbf{m i n}-\mathbf{m a x}), \mathbf{~ m g ~}^{\mathbf{a}}$ & $\mathbf{U L S C}(\mathbf{m i n}-\mathbf{m a x}), \mathbf{m g}{ }^{\mathbf{a}}$ & $\begin{array}{l}\text { Range of experimental } \\
\text { observations, } \mathbf{m g} / \mathbf{k g}\end{array}$ & Safe intake, g/day & Producer \\
\hline $\mathbf{C u}$ & $0,6-10$ & $10-12$ & $5-12$ & 1000 & 1 \\
\hline $\mathbf{F e}$ & $8-60$ & 45 & $26-56$ & 800 & 2 \\
\hline $\mathbf{M n}$ & $0,3-8$ & 11 & $56-138$ & 80 & 3 \\
\hline $\mathbf{Z n}$ & $8-18$ & $40-50$ & $16-31$ & 1600 & 1 \\
\hline Co & $0.02-0.04$ & 0.6 & $0.04-0.34$ & 2300 & 1 \\
\hline Cd & & 0.02 & $0.8-0.9$ & 22 & 3 \\
\hline Pb & 0.1 & $0.3-0.6$ & 160 & 3 \\
\hline
\end{tabular}

a Exposures, reported in $\mathrm{mg} / \mathrm{kg}$ of human body weight, were recalculated into mg assuming an arbitrary adult human body mass of $60 \mathrm{~kg}$ for either sex.

\section{Principal Component Analysis:}

Evidently, the chemical composition and properties of plants are determined by an ensemble of available chemical elements and compounds. Therefore, a transition from a large number of variables to a limited number of new variables that would adequately describe the collective effect of all presented chemical elements simplifies a multi-component system. We used PCA to describe variability among observed, correlated variables in terms of a potentially lower number of unobserved variables called principal components.

The PCA of St John's wort samples was performed with the use of the literature data. The composition of 71 samples of SJW was described in ${ }^{16,25-35}$ and 12 elements, namely $\mathrm{Al}, \mathrm{B}, \mathrm{Ba}, \mathrm{Ca}, \mathrm{Cu}, \mathrm{Fe}, \mathrm{Mg}, \mathrm{Mn}, \mathrm{Ni}, \mathrm{Pb}, \mathrm{Sr}$ and
$\mathrm{Zn}$, were recorded in most of these papers. The task of PCA was to analyse the behaviour of 12 chemical elements in the studied plant with the use of a smaller number of new variables. A data matrix composed of 12 variables and 71 cases was formed. As follows from Table 6, the chemical composition of the studied plant can be described by introducing only three new components. The first PC represents only $38.88 \%$ of the total variance, while all three PCs cover 91.4\%. Each new component is a linear combination of the concentrations of chemical elements of which it is composed.

The PC graph in reciprocal space is shown in Fig. 4. The first component is composed of essential $\mathrm{Zn}$ and $\mathrm{Fe}$ in combination with impurity metals $\mathrm{Al}$ and $\mathrm{Ba}$. Three of four elements show a strong positive correlation with this component, and the fourth element $(\mathrm{Ba})$ has a strong negative correlation. 
Table 6: Total Variance Explained

\begin{tabular}{|l|l|l|l|l|l|l|}
\hline PC & \multicolumn{2}{|l|}{ Initial eigenvalues } & \multicolumn{3}{l|}{ Rotation sums of squared loading } \\
\hline & Total & \% of Variance & Cumulative \% & Total & \% of Variance & Cumulative \% \\
\hline $\mathbf{1}$ & 4.67 & 38.88 & 38.88 & 4.30 & 35.83 & 35.83 \\
\hline $\mathbf{2}$ & 3.58 & 29.82 & 68.70 & 3.87 & 32.26 & 68.08 \\
\hline $\mathbf{3}$ & 2.72 & 22.70 & 91.40 & 2.80 & 23.32 & 91.40 \\
\hline $\mathbf{4}$ & 1.03 & 8.60 & 100.00 & & & \\
\hline $\mathbf{5}$ & $9.8 \times 10^{-16}$ & $8.2 \times 10^{-15}$ & 100.00 & & & \\
\hline $\mathbf{6}$ & $6.1 \times 10^{-16}$ & $5.1 \times 10^{-15}$ & 100.00 & & & \\
\hline
\end{tabular}

The share of PC 2 is almost $30 \%$ of the total variance. It is based on essential macronutrient $\mathrm{Ca}$, which together with non-essential $\mathrm{Sr}$ and $\mathrm{Ni}$ forms a positive correlation with the component 2. Toxic $\mathrm{Pb}$ impurity has a strong negative correlation with the component 2 . The third PC includes essential macroelement $\mathrm{Mg}$ and trace elements $\mathrm{Mn}$ and $\mathrm{Cu}$. It explains almost $23 \%$ of the total variance. The correlations are positive for $\mathrm{Mg}$ and $\mathrm{Mn}$ and negative for $\mathrm{Cu}$ because component 3 increases with decreasing $\mathrm{Cu}$ content. The fact that the studied essential elements belong to different principal components illustrates the relative independence of changes in concentrations of these elements in various samples.

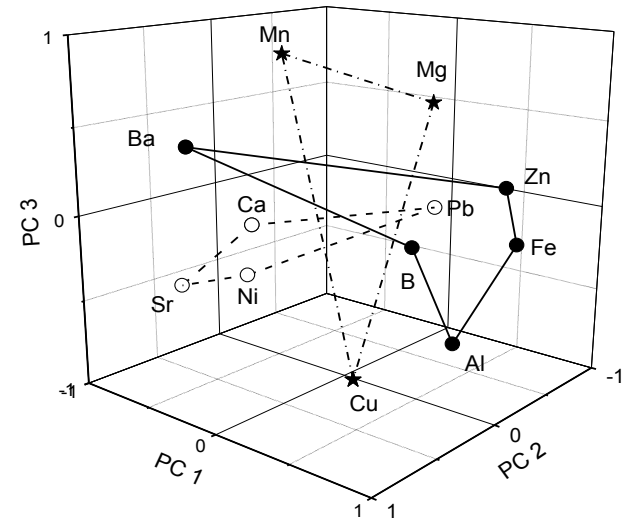

Fig. 4: Principal components plot in rotated space for St John's wort

\section{CONCLUSIONS:}

The concentrations of essential microelements $\mathrm{Fe}, \mathrm{Cu}$, $\mathrm{Mn}$ and $\mathrm{Zn}$ and toxic metals $\mathrm{Pb}, \mathrm{Cd}, \mathrm{Co}$ and $\mathrm{Cr}$ were studied by FAAS in samples of herbal medicine $\mathrm{St}$ John's wort which were grown in Ukraine and supplied by three different producers of medicinal herbs 400-500 $\mathrm{km}$ distant from one another. The experimental data obtained were compared with the results of 12 research works which studied 71 samples of St John's wort. The $\mathrm{Cu}$ content fluctuates between 5 and $12 \mu \mathrm{g} / \mathrm{g}$ in the experimental samples and is weakly dependent on the producer name. No statistically significant difference in $\mathrm{Fe}, \mathrm{Zn}$ and $\mathrm{Pb}$ concentrations exists between samples of different producers. The $\mathrm{Cr}$ concentration is below the detection limits in all studied specimens. In contrast, the concentrations of $\mathrm{Mn}, \mathrm{Cd}$ and $\mathrm{Co}$ in samples of different producers differ from each other. Samples of producer 3 demonstrate the highest $\mathrm{Mn}$ and $\mathrm{Zn}$ contents and simultaneously the lowest Fe concentration. Samples of producer 3 show measurable $\mathrm{Cd}$ concentrations and samples of producers 1 and 3 reveal Co. In other samples, both these elements are below the detection limits. The measured $\mathrm{C}_{\mathrm{m}}(\exp )$ values are in the vicinity of $0.85 \mu \mathrm{g} / \mathrm{g}$ for $\mathrm{Cd}$ and $0.2 \mu \mathrm{g} / \mathrm{g}$ for Co that is very close to the average figures derived from the literature data. The toxic metal, $\mathrm{Pb}$, is detected in all plants, fluctuating between 0.32 and $0.61 \mu \mathrm{g} / \mathrm{g}$. The measured concentrations of both $\mathrm{Pb}$ and $\mathrm{Cd}$ still secure against overuse of toxic metals with herbal remedies. However, the limits of tolerable daily intakes are not so far from the doses which can be accumulated in the course of very intensive consumption of at least the most contaminated herbs. The measured average concentrations of $\mathrm{Cu}, \mathrm{Co}, \mathrm{Mn}$ and $\mathrm{Cd}$ are comparable in magnitude with the mean concentrations derived from the literature data. The measured $\mathrm{C}_{\mathrm{m}}(\exp )$ values for $\mathrm{Zn}$, $\mathrm{Fe}, \mathrm{Pb}$ and $\mathrm{Cr}$ are in average lower than $\mathrm{C}_{\text {med }}$ (lit) reported in the literature. The application of PCA to an array of the published data allows one to explain the total variance with a lower number of variables. In particular, the chemical composition of St John's wort samples is described by introducing only three new principal components which represent $91 \%$ of the total variance. Primary essential elements are uniformly distributed among all three principal components. Each component explains $39 \%$ to $23 \%$ of the total variance.

\section{REFERENCES:}

1. Kaviarasan L, Sarojini S, Prakash Yoganandam G, Gopal V. Preparation and Standardization of Deepavali Avaleha - A Traditional Polyherbal Ayurvedic Formulation. Asian Journal of Pharmacy and Technology. 2016; 6(4): 231-237. Doi: 10.5958/22315713.2017.00016.2

2. Chirag P, Tyagi S, Pinkesh P, Yadav A. Phytosomes: A Current Trend for Enhancement of Bioavailability of Polar Phytoconstituents. Research Journal of Pharmaceutical Dosage Forms and Technology. 2014; 6(1): 44-49.

3. Lynch N, Berry D. Differences in perceived risks and benefits of herbal, over-the-counter conventional, and prescribed conventional, medicines, and the implications of this for the safe and effective use of herbal products. Complementary Therapies in Medicine. 2007; 15: 8491. DOI: 10.1016/j.ctim.2006.06.007

4. Prasha D, Saklani S. Pharmaceutical and Economical Aspects of Medicinal Herbs: An Overview. Research Journal of Pharmacognosy and Phytochemistry. 2011; 3(5): 187-190.

5. Kristanc L, S. Kreft S. European medicinal and edible plants associated with subacute and chronic toxicity part I: Plants with carcinogenic, teratogenic and endocrine-disrupting effects. Food and Chemistry Toxicology. 2016; 92: 150-164. DOI: 10.1016/j.fct.2016.04.007 
6. Kristanc L, Kreft S. European medicinal and edible plants associated with subacute and chronic toxicity part II: Plants with hepato-, neuro-, nephro- and immunotoxic effects. Food and Chemistry Toxicology. 2016; 92: 38-49. doi: 10.1016/j.fct.2016.03.014.

7. Rungsung W, Dutta S, Hazra J. Pharmacognostical Approach towards Authentication and Quality Evaluation of Medicinal Plants-A Compendious Description. Research Journal of Pharmacognosy and Phytochemistry. 2013; 5(2) 77-83.

8. Locatelli C, Melucci D, Locatelli M. Toxic metals in herbal medicines. A review. Current Bioactive Compounds. 2014; 10: 181-188.

9. Chizzola R. Metallic mineral elements and heavy metals in medical plants. Medicinal and Aromatic Plant Science and Biotechnology. 2012; 6: 39-53.

10. Patel S, Apte M. A Review on Significances of Impurity Profiling. Research Journal of Pharmaceutical Dosage Forms and Technology. 2016; 8(1): 31-36.

11. Pohl P, Dzimitrowicz A, Jedryczko D, Szymczycha-Madeja A, Welna $M$, Jamroz P. The determination of elements in herbal teas and medicinal plant formulations and their tisanes. Journal of Pharmaceutical and Biomedical Analysis. 2016; 130: 326-335. https://doi.org/10.1016/j.jpba.2016.01.042

12. Priya S, Nethaji S. Phytochemical Screening and Trace Element Analysis of Diospyros virginiana. Research Journal of Pharmacology and Pharmacodynamics. 2014; 6(1): 05-07.

13. Joshi RK, Joshi BC, Sati MK. Chemical and Chemotaxonomic Aspects of Some Aromatic and Medicinal Plants Species from Utrrakhand: A Review. Asian Journal of Pharmacy and Technology. 2014; 4(3): 157-162.

14. Ličina VD, Jelačić SC, Beatović DV, Antić Mladenović SB. Mineral composition of different basil (Ocimum spp.) genotypes. Hemijska industrija. 2014; 68: 501-510. doi: 10.2298/HEMIND130314075L

15. Kabata-Pendias A. Trace Elements in Soils and Plants, fourth ed. CRC Press, Boca Raton, Fl, USA. 2011.

16. Radanovic D, Antic-Mladenovic S, Jakovljevic M. Influence of some soil characteristics on heavy metal content in Hypericum perforatum L. and Achillea millefolium L. Acta Horticulturae. 2002; 576: 295301. DOI: 10.17660/ActaHortic.2002.576.44

17. Zhang J, Wider B, Shang H, Li X, Ernst E. Quality of herbal medicines: Challenges and solutions. Complementary Therapies in Medicine. 2012; 20: 100-106. doi: 10.1016/j.ctim.2011.09.004

18. Gil F, Hernández AF and Martín-Domingo MC. Toxic Contamination of Nutraceuticals and Food Ingredients. In Nutraceuticals: Efficacy, Safety and Toxicity. Edited by Gupta RC. Elsevier Inc, Amsterdam. 2016; pp. 825-837. DOI: http://dx.doi.org/10.1016/B978-0-12-8021477.00058-9

19. Bais SK, Chandewar AV, Wargantiwar DW, Charjan SM. Comparative Evaluation of Heavy Metals in Marketed Haematinic Herbal Formulations by Atomic Absorption Spectroscopy. Asian Journal of Pharmaceutical Analysis. 2014; 4(1): 11-16.

20. Goldhaber SB. Trace element risk assessment: essentiality vs. toxicity. Regulatory Toxicology and Pharmacology. 2003; 38: 232-242. doi:10.1016/S0273-2300(02)00020-X

21. Good Agricultural and Collection Practice for Herbal Raw Materials (Botanical Raw Materials Committee of the American Herbal Products Association, American Herbal Pharmacopoeia). 2006. 39 p. Available from: http://www.herbal-ahp.org/06_1208_AHPA-AHP_GACP.pdf (accessed 01.08.17).

22. Shinde PS, Mahadik VJ, Sarvagod SM. Herbal drug standardization and its implication - A current need of time. Research Journal of Pharmacognosy and Phytochemistry. 2016; 8(2): 93-100. DOI 10.5958/0975-4385.2016.00018.2

23. Wanjari AS, Magar S, Chapalgaokar S, Chouragade NB, Wanjari DS. Evaluation and Standardization of Herbal Formulation. Research Journal of Pharmacognosy and Phytochemistry. 2016; 8(3): 133-140.

24. Q3D Elemental Impurities. Guidance for Industry. ICH, USA. 2015.

25. Pytlakowska K, Kita A, Janoska P, Polowniak M, Kozik V. Multielement analysis of mineral and trace elements in medicinal herbs and their infusions. Food Chemistry. 2012; 135: 494-501 http://dx.doi.org/10.1016/j.foodchem.2012.05.002

26. Tokalioglu S. Determination of trace elements in commonly consumed medicinal herbs by ICP-MS and multivariate analysis. Food Chemistry. $\quad 2012 ; \quad$ 134: 2504-2508 http://dx.doi.org/10.1016/j.foodchem.2012.04.093

27. Mihaljev Z, Zivkov-Balos M, Cupic Z, Jaksic S. Levels of some microelements and essential heavy metals in herbal teas in Serbia.
Acta Pol. Pharm. 2014; 71: 385-391.

28. Igamberdieva PK, Usmanov RD, Danilova EA. Investigation of macro- and trace element composition of medicinal plants of southern Fergana and prospects of their application in the treatment of diseases. Mikroelementy v Meditsine. 2016; 17(3): 48-53 (in Russian). DOI: 10.19112/2413-6174-2016-17-3-48-53

29. Gomez MR, Cerutti S, Sombra LL, Silva MF, Martınez LD. Determination of heavy metals for the quality control in Argentinian herbal medicines by ETAAS and ICP-OES. Food and Chemistry Toxicology. 2007; 45: 1060-1064. doi:10.1016/j.fct.2006.12.013

30. Filipiak-Szok A, Kurzawa M, Szlyk E. Determination of toxic metals by ICP-MS in Asiatic and European medicinal plants and dietary supplements. Journal of Trace Elements in Medicine and Biology. 2015; 30: 54-58. http://dx.doi.org/10.1016/j.jtemb.2014.10.008

31. Bu K, Cizdziel JV, Reidy L. Analysis of herbal supplements for selected dietary minerals and trace elements by laser ablation- and solution-based ICPMS. Microchemical Journal. 2013; 106: 244-249. http://dx.doi.org/10.1016/j.microc.2012.07.011

32. Siromlya TI, Zagurskaya YuV, Bayandina II. The elemental composition of the extracts from the herb Hypericum Perforatum L. grown in the regions with high technogenic load. Vestnik Orenburgskogo GosUniversiteta. 2015; 185(10): 77-81 (in Russian).

33. Kalny P, Fijałek Z, Daszczuk A, Ostapczuk P. Determination of selected microelements in polish herbs and their infusions. Science of The Total Environment. 2007; 381: 99-104. doi:10.1016/j.scitotenv.2007.03.026

34. Owen JD. Investigation of the elemental profiles of Hypericum perforatum as used in herbal remedies. Doctoral Thesis. The University of Hertfordshire, UK. 2013.

35. Chizzola R, B. Lukas B. Variability of the cadmium content in Hypericum species collected in eastern Austria. Water, Air and Soil Pollution. 2005; 170: 331-343. DOI: 10.1007/s11270-005-9004-y

36. Mamani MCV, Aleixo LM, Abreu, MFd, Rath S. Simultaneous determination of cadmium and lead in medicinal plants by anodic stripping voltammetry. Journal of Pharmaceutical and Biomedical $\begin{array}{llll}\text { Analysis. } & 2005 ; & 37(4): & 709-713\end{array}$ https://doi.org/10.1016/j.jpba.2004.11.049

37. Hussain J, Bahader A, Ullah F, Rehman NU, Khan AL, Ullah W, Shinwari ZK. Proximate and Nutrient Analysis of the Locally Manufactured Herbal Medicines and its Raw Material. Journal of American Science. 2010; 6(5): 91-96.

38. Prokopchuk O, Hrubinko V. Heavy metals in the small rivers of Ternopil region under different types of anthropogenic pressure. Vìsnyk Dnìpropetrovskogo Unìversiteta. Seria. Bìologia i Ekologia. 2016; 24(1): 173-181 (in Ukrainian). doi:10.15421/011621

39. WHO guidelines for assessing quality of herbal medicines with reference to contaminants and residues. WHO Press, Geneva. 2007.

40. US Pharmacopeia, <232> Elemental Impurities - Limits. In US Pharmacopeia. The United States Pharmacopeial Convention. Edition 2013; pp.151-153.

41. Guideline on the specification limits for residues of metal catalysts or metal reagents. European Medicines Agency, Doc. Ref. EMEA/CHMP/SWP/4446/2000. EMA, London. 2008.

42. Commission Regulation (EC) No 1881/2006 of 19 December 2006 setting maximum levels for certain contaminants in foodstuffs. Official Journal of the EU. 20.12.2006. L364/5-L364/34. Available from: http://data.europa.eu/eli/reg/2006/1881/2016-04-01 (accessed 01.08.17).

43. Heavy Metals: Analysis and Limits in Herbal Dietary Supplements. AHPA, USA. 2009.

44. Dietary supplements. Standard NSF/ANSI 173-2016. USA. 2016. 